$\begin{array}{ll}\text { Volume } & : 04 \\ \text { Nomor } & : 03 \\ \text { Bulan } & : \text { September } \\ \text { Tahun } & : 2018 \\ \text { http } & : \text { //ejurnal.pps.ung.ac.id/index.php/AKSARA/index }\end{array}$

\title{
Meningkatkan Kemampuan Menceritakan Isi Bacaan Melalui Pendekatan Komunikatif Pada Siswa Kelas IV di SDN 1 Limboto Barat Kabupaten Gorontalo
}

\author{
Febriati Simin, Yusuf Jafar \\ Universitas Negeri Gorontalo \\ febriatisimin@gmail.com
}

\begin{abstract}
ABSTRAK
Permasalahan dalam penelitian adalah "Apakah melalui pendekatan komunikatif dapat meningkatkan kemampuan menceritakan isi bacaan pada siswa kelas IV di SDN 1 Limboto Barat Kabupaten Gorontalo?". Tujuan penelitian ini adalah untuk meningkatkan kemampuan siswa menceritakan isi bacaan melalui pendekatan komunikatif. Metode penelitian yang digunakan adalah penelitian tindakan kelas dengan menggunakan teknik pengumpulan data observasi, tes perbuatan, dan dokumentasi. Hasil penelitian menunjukkan bahwa dari 14 siswa kelas IV SDN 1 Limboto Barat Kabupaten Gorontalo berdasarkan hasil observasi awal terdapat 5 orang siswa (36\%) yang mampu menceritakan isi bacaan dengan baik, sedangkan siswa yang belum mampu berjumlah 9 orang (64\%). Pada tindakan siklus I tahap I terdapat 6 orang siswa (43\%) yang mampu dan yang belum mampu 8 orang siswa (57\%). Siklus I tahap II terdapat 9 orang siswa (64\%) yang mampu dan yang belum mampu 5 orang siswa (36\%). Pada tindakan siklus II, siswa yang mampu berjumlah 12 orang $(86 \%)$ sedangkan siswa yang belum mampu berjumlah 2 orang (14\%). Dengan demikian dapat disimpulkan bahwa pendekatan komunikatif telah meningkatkan kemampuan siswa menceritakan isi bacaan di Kelas IV SDN 1 Limboto Barat Kabupaten Gorontalo.
\end{abstract}

\section{Kata Kunci : Menceritakan Isi Bacaan, Pendekatan Komunikatif}

\section{PENDAHULUAN}

Pembelajaran bahasa Indonesia sangat penting peranannya dalam menumbuh kembangkan kemampuan berbahasa peserta didik. Kemampuan berbahasa yang baik dapat menentukan keberhasilan komunikasi dalam kehidupan masyarakat yang serba modern seperti sekarang ini. Salah satu bentuk kemampuan siswa dalam berkomunikasi ditunjukkan dengan kemampuan siswa dalam bercerita. Bercerita merupakan kegiatan menyampaikan sesuatu kepada orang lain. Hal ini diperjelas dengan pendapat Bachir (dalam Suwarti, 2009:246) bercerita adalah menuturkan sesuatu yang mengisahkan tentang perbuatan atau sesuatu kejadian dan disampaikan secara lisan dengan tujuan membagikan pengalaman dan pengetahuan kepada orang lain.

Kemampuan siswa dalam bercerita yang diharapkan, dapat teraktualisasi melalui kemampuan siswa dalam menceritakan isi bacaan secara runtut, menggunakan bahasa yang baik serta mampu mengungkapkan isi bacaan secara lisan dengan menggunakan kata-kata sendiri dan memperhatikan aspek-aspek yang dinilai. Aspek yang dinilai tersebut yakni lafal, intonasi, ketepatan isi cerita, pilihan kata, struktur kalimat, dan kelancaran. Jika siswa sudah mampu menceritakan isi 


$\begin{array}{ll}\text { Volume } & : 04 \\ \text { Nomor } & : 03 \\ \text { Bulan } & : \text { September } \\ \text { Tahun } & : 2018 \\ \text { http } & : / / \text { jurnal.pps.ung.ac.id/index.php/AKSARA/index }\end{array}$

bacaan dengan lancar berarti siswa sudah mampu memahami isi bacaan dengan baik.

Hal ini didukung dari hasil observasi awal yang dilakukan di kelas IV SDN 1 Limboto Barat Kabupaten Gorontalo bahwa dari 14 jumlah siswa, yang mampu menceritakan isi bacaan dengan baik sekitar 5 orang siswa (36\%) dan siswa yang belum mampu berjumlah 9 orang siswa (64\%). Dari hasil penelitian tersebut masih banyak siswa yang belum mampu menceritakan kembali isi bacaan, maka hal ini menjadi tugas guru dan peneliti terhadap proses pembelajaran untuk mencari solusi dalam meningkatkan kemampuan siswa menceritakan isi bacaan tersebut.

Salah satu cara yang dapat digunakan untuk meningkatkan kemampuan siswa dalam proses pembelajaran terutama tentang bercerita yaitu dengan menggunakan pendekatan komunikatif. Pendekatan komunikatif merupakan pendekatan yang berlandaskan pada pemikiran bahwa kemampuan menggunakan bahasa dalam berkomunikasi merupakan tujuan yang harus dicapai dalam pembelajaran bahasa. Hal ini diperkuat dengan pendapat Sani (2013:267) yang menyatakan bahwa pendekatan komunikatif mengarahkan pengajaran bahasa pada tujuan pengajaran yang mementingkan fungsi bahasa sebagai alat komunikasi. Pendekatan komunikatif dianggap pendekatan yang tepat karena mampu melatih siswa dalam bercerita dan mengembangkan kemampuan berbahasa.

\section{Pengertian Kemampuan}

Kemampuan adalah kesanggupan, kecakapan dan kekuatan seseorang dalam melakukan sesuatu pekerjaan dengan cepat dan benar. Hal ini diperkuat dengan pendapat Spencer and Spencer (dalam Uno, 2008:62) mendefinisikan kemampuan sebagai karakteristik yang menonjol dari seorang individu yang berhubungan dengan kinerja afektif dan superior dalam suatu pekerjaan atau situasi. Menurut Mohammad Zain (dalam Yusdi, 2010:10) menyatakan kemampuan yakni kesanggupan, kecakapan, dan kekuatan kita berusaha dengan diri sendiri. Dapat disimpulkan bahwa kemampuan adalah kesanggupan yang dimiliki oleh seseorang dalam melakukan suatu pekerjaan.

\section{Pengertian Bercerita}

Bercerita adalah menuturkan sesuatu yang mengisahkan tentang perbuatan atau suatu kejadian secara lisan dalam upaya untuk mengembangkan potensi kemampuan berbahasa. Menurut Subyantoro (2013:35) bercerita merupakan suatu kegiatan yang bersifat seni, karena erat kaitannya dengan keindahan dan bersandar kepada kekuatan kata-kata. Kekuatan kata-kata inilah, yang dipergunakan untuk mencapai tujuan bercerita. Sedangkan Mulyati (dalam Widasari, 2012:10) mengemukakan bahwa bercerita merupakan salah satu keterampilan berbahasa yang bersifat produktif yang menghasilkan ide, gagasan, dan buah pikiran.

\section{Tujuan Bercerita}

Tujuan umum bercerita adalah menyampaikan informasi atau berkomunikasi dengan orang lain. Agar dapat menyampaikan informasi secara efektif, seorang yang bercerita harus memahami segala makna yang disampaikan. Tarigan (dalam firdaus, 2013:12) mengungkapkan tiga tujuan umum dari kegiatan 


$\begin{array}{ll}\text { Volume } & : 04 \\ \text { Nomor } & : 03 \\ \text { Bulan } & : \text { September } \\ \text { Tahun } & : 2018 \\ \text { http } & : / / \text { jurnal.pps.ung.ac.id/index.php/AKSARA/index }\end{array}$

bercerita sebagai berikut: (a) memberitahukan dan melaporkan, (b) menjamu dan menghibur, (c) membujuk, mengajak, mendesak, dan meyakinkan.

\section{Kelebihan dan Kekurangan dalam Bercerita}

Kelebihan dan kekurangan dalam bercerita menurut Dhieni, (2005-3-31). Kelebihannya antara lain: (a) Dapat menjangkau jumlah anak yang relatif lebih banyak, (b) Waktu yang tersedia dapat dimanfaatkan dengan efektif dan efisien, (c) Pengaturan kelas menjadi lebih sederhana, (d) Guru dapat menguasai kelas dengan mudah, (e) Secara relatif tidak banyak memerlukan biaya. Kekurangannya antara lain: (a) Anak didik menjadi pasif karena lebih banyak mendengarkan atau menerima penjelasan dari guru, (b) Kurang merangsang perkembangan kreatifitas dan kemampuan siswa untuk mengutarakan pendapatnya, (c) Daya serap atau daya tangkap anak didik berbeda dan masih lemah sehingga sukar memahami tujuan pokok isi cerita, (d) Cepat menumbuhkan rasa bosan terutama apabila penyajiannya tidak menarik.

\section{Prosedur Pembelajaran Pendekatan Komunikatif}

Prosedur pembelajaran berdasarkan pendekatan komunikatif menurut Syakur (2009:192-193) yaitu:

a. Penyajian dialog singkat

b. Pelatihan setiap ujaran yang diambil dari dialog

c. Tanya jawab yang didasarkan pada topik dan situasi dialog dan dihubungkan dengan pengalaman-pengalaman pribadi siswa, tetapi berkisar pada tema dialog.

d. Pengkajian (siswa diajak untuk mengkaji salah satu ungkapan yang terdapat dalam dialog.

e. Penemuan generalisasi atau kaidah-kaidah yang mendasari ungkapan fungsional atau struktur oleh siswa.

f. Pengenalan lisan dan kegiatan produksi lisan dimulai dari kegiatan komunikasi terbimbing sampai yang lebih bebas.

g. Menyalin dialog atau modul bila tidak ada di dalam teks pelajaran.

h. Evaluasi belajar (hanya berbentuk lisan)

\section{Metode Penelitian}

Penelitian tindakan kelas ini dilaksanakan di SDN 1 Limboto Barat, Kabupaten Gorontalo tahun pelajaran 2017/2018. Jumlah siswa SDN 1 Limboto Barat terdiri dari laki-laki 32 orang dan perempuan 68 orang, jumlah total 100 orang, namun siswa yang akan diteliti adalah siswa kelas IV sebanyak 14 orang dengan jumlah laki-laki 5 orang dan perempuan 9 orang. Variabel dalam penelitian ini adalah variabel input, proses dan output. Penelitian tindakan kelas (PTK) menurut (Tampubolon, 2014:19) adalah penelitian praktis di dalam kelas untuk memperbaiki kualitas proses pembelajaran, meningkatkan hasil belajar, dan menemukan model pembelajaran inovatif untuk memecahkan masalah yang dialami oleh pendidik dan peserta didik.

Berikut ini adalah skema prosedur penelitian tindakan kelas menurut Kemmis dan Taggart (Dalam Khasanah, 2016: 22). 


$\begin{array}{ll}\text { Volume } & : 04 \\ \text { Nomor } & : 03 \\ \text { Bulan } & : \text { September } \\ \text { Tahun } & : 2018 \\ \text { http } & : / / \text { jurnal.pps.ung.ac.id/index.php/AKSARA/index }\end{array}$

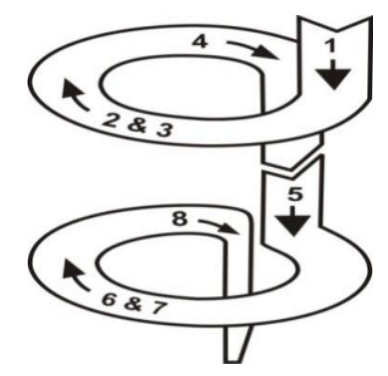

Keterangan:

Sikus I

1. Perencanaan

2. Pelaksanaan Tindakan

3. Pemantauan dan Evaluasi

4. Analisis dan Refleksi

Siklus II

1. Perencanaan

2. Pelaksanaan Tindakan

3. Pemantauan dan Evaluasi

4. Analisis dan Refleksi

Teknik pengumpulan data penelitian dilakukan melalui observasi, tes perbuatan dan dokumentasi. Untuk menghitung persentase kemampuan menceritakan isi bacaan pada siswa menggunakan rumus sebagai berikut, Sugiyono (dalam Khasanah, 2016:26).

Keterangan:

$$
\mathrm{P}=\frac{f}{n} \times 100 \%
$$

$\mathrm{P}=$ Persentase

$\mathrm{f}=$ Jumlah Siswa yang Mampu menceritakan isi bacaan

$\mathrm{n}=$ Jumlah Siswa

$100 \%=$ Bilangan Tetap

\section{Hasil Penelitian}

Dari hasil observasi yang dilakukan peneliti, terdapat beberapa masalah yang ditemui dalam pembelajaran bahasa Indonesia khususnya dalam menceritakan isi bacaan. Kemampuan siswa dalam menceritakan isi bacaan, belum sesuai dengan harapan. Hal ini dibuktikan dengan kenyataan yang ada di lapangan bahwa dari 14 jumlah siswa keseluruhan, yang memiliki kemampuan menceritakan isi bacaan sesuai dengan harapan sekitar 5 orang (36\%), sedangkan 9 siswa (64\%) lainnya belum sesuai dengan harapan, maka peneliti memutuskan untuk melanjutkan penelitian ke tahap berikutnya yaitu ke Tahap Siklus I. Pada tahap siklus I, peneliti menemukan banyaknya siswa yang mengalami kendala dalam menceritakan isi bacaan. Terbukti bahwa rendahnya kemampuan siswa dalam menceritakan isi bacaan karena banyak siswa yang belum mencapai inidikator kinerja yang telah ditetapkan yaitu 75\%. Sesuai hasil analisis data pada kegiatan Siklus I Tahap I, dapat diketahui bahwa terdapat 6 siswa (43\%) yang mampu menceritakan isi bacaan sedangkan 8 siswa (57\%) lainnya belum mampu menceritakan isi bacaan. Hal ini berarti masih banyak siswa yang belum mencapai indikator kinerja, untuk itu peneliti bersama guru mitra melakukan kegiatan refleksi untuk menilai kegiatan pembelajaran yang dilaksanakan pada siklus I tahap I.

Berdasarkan hasil refleksi, maka peneliti dan guru mitra menetapkan beberapa kelemahan yang ditemui pada pelaksanaan kegiatan pembelajaran. Kelemahan-kelemahan tersebut yaitu: (1) Siswa belum berani maju di depan kelas, (2) Siswa terlihat bingung untuk memulai dalam bercerita, (3) Siswa belum 
memahami isi bacaan, (4) Siswa belum memahami tentang kata-kata sulit yang terdapat dalam bacaan, (5) Siswa sulit mengucapkan kata-kata dalam bacaan yang berbahasa Gorontalo, (6) Dari enam aspek yang dinilai banyak siswa mengalami kekurangan-kekurangan pada aspek intonasi, ketepatan isi cerita, dan kelancaran, (7) Cara guru dalam mengajar belum maksimal, (8) Kemampuan siswa dalam menceritakan isi bacaan melalui pendekatan komunikatif masih rendah dibuktikan dengan adanya nilai siswa yang belum mencapai indikator kinerja yang telah ditetapkan yakni $75 \%$.

Sesuai hasil refleksi yang dilakukan dapat dijelaskan bahwa tindakan siklus I tahap I terdapat banyak siswa yang mengalami kendala dan belum mencapai kriteria keberhasilan yang ditetapkan, maka peneliti dan guru mitra memutuskan untuk diadakannya tindakan perbaikan pada siklus I tahap II sebagai penyempurnaan dari siklus sebelumnya (siklus I tahap I). Sesuai hasil analisis data pada kegiatan Siklus I Tahap II dapat diketahui bahwa dari 14 jumlah siswa keseluruhan, terdapat 9 siswa (64\%) yang mampu menceritakan isi bacaan sedangkan 5 siswa $(36 \%)$, hal ini berarti terdapat 5 siswa yang belum mencapai indikator kinerja. Untuk itu peneliti bersama guru mitra melakukan kegiatan refleksi untuk menilai kegiatan pembelajaran yang dilaksanakan pada siklus I tahap II.

Berdasarkan hasil refleksi, maka peneliti dan guru mitra menetapkan beberapa kelemahan yang ditemui pada pelaksanaan kegiatan pembelajaran siklus I tahap II. Kelemahan-kelemahan tersebut yaitu: (1) Siswa kurang memahami isi bacaan, (2) Siswa sulit mengucapkan kata-kata dalam bacaan yang berbahasa Gorontalo, (3) Dari enam aspek yang dinilai banyak siswa mengalami kekurangan-kekurangan pada aspek kelancaran, (4) Cara guru dalam mengajar belum maksimal, (5) Kemampuan siswa dalam menceritakan isi bacaan melalui pendekatan komunikatif masih rendah dibuktikan dengan adanya nilai siswa yang belum mencapai indikator kinerja yang telah ditetapkan yakni $75 \%$.

Berikut rekapitulasi kemampuan siswa menceritakan isi bacaan melalui pendekatan komunikatif dari tahap observasi hingga siklus II dapat dilihat pada tabel berikut:

Tabel Rekapitulasi Kemampuan Siswa Menceritakan Isi Bacaan melalui Pendekatan Komunikatif

\begin{tabular}{|l|l|c|c|}
\hline \multirow{2}{*}{ No } & \multirow{2}{*}{ Tahap Pelaksanaan } & $\begin{array}{c}\text { Presentase Kemampuan siswa Menceritakan Isi } \\
\text { Bacaan }\end{array}$ \\
\cline { 3 - 4 } & & \multicolumn{2}{|c|}{$\begin{array}{c}\text { Mampu } \\
\text { Mampu }\end{array}$} \\
\hline 1. & Observasi & $36 \%$ & $64 \%$ \\
\hline 2. & Siklus I & $43 \%$ & $57 \%$ \\
\hline & - Tahap I & $64 \%$ & $36 \%$ \\
\hline & - Tahap II & $86 \%$ & $14 \%$ \\
\hline 3. & Siklus II & & \\
\hline
\end{tabular}

Dengan demikian dapat disimpulkan bahwa kegiatan siklus II ini dinilai telah berhasil dan tidak perlu lagi dilanjutkan pada siklus berikutnya. 


$\begin{array}{ll}\text { Volume } & : 04 \\ \text { Nomor } & : 03 \\ \text { Bulan } & : \text { September } \\ \text { Tahun } & : 2018 \\ \text { http } & : / / \text { ejurnal.pps.ung.ac.id/index.php/AKSARA/index }\end{array}$

\section{Pembahasan}

Tujuan dalam penelitian ini yaitu untuk meningkatkan kemampuan menceritakan isi bacaan melalui pendekatan komunikatif pada siswa kelas IV di SDN 1 Limboto Barat Kabupaten Gorontalo. Maka untuk mencapai tujuan penelitian dan menjawab rumusan masalah, peneliti melakukan tes terhadap kemampuan siswa dalam menceritakan isi bacaan. Berdasarkan rumusan masalah dan tujuan penelitian tersebut telah diperoleh hasil bahwa pendekatan komunikatif dapat meningkatkan kemampuan menceritakan isi bacaan siswa kelas IV di SDN 1 Limboto Barat Kabupaten Gorontalo.

Pengertian dari menceritakan atau bercerita, menurut Bachir (dalam Suwarti, 2009:246) bercerita adalah menuturkan sesuatu yang mengisahkan tentang perbuatan atau sesuatu kejadian dan disampaikan secara lisan dengan tujuan membagikan pengalaman dan pengetahuan kepada orang lain. Dalam bercerita ataupun menceritakan isi bacaan terdapat beberapa aspek yang dinilai diantaranya lafal, intonasi, ketepatan isi cerita, pilihan kata, struktur kalimat dan kelancaran.

Dari hasil tes menceritakan isi bacaan dapat diketahui bahwa dari enam aspek yang dinilai terdapat beberapa siswa yang mampu dan tidak mampu dalam menceritakan isi bacaan. Adapun yang menjadi kendala siswa dalam menceritakan isi bacaan yaitu dalam penggunaan lafal dan intonasi kurang jelas karena siswa tidak terlalu membuka mulut sehingga pengucapan huruf, kata maupun kalimat tidak terdengar jelas. Selain itu, ada siswa yang hanya menceritakan isi bacaan pada awal kalimat dan ada juga siswa yang menceritakan isi bacaan tidak secara sistematis (berurutan). Hal ini disebabkan oleh kurangnya pemahaman siswa terhadap isi bacaan. Kemudian terdapat juga siswa yang terbata-bata (tidak lancar) dalam menceritakan isi bacaan karena belum berani (takut) dalam mengungkapkan isi bacaan sehingga dalam menceritakan suaranya kecil. Mengingat karena masih banyak siswa yang mengalami kendala dalam menceritakan isi bacaan, maka peneliti dan guru mitra berupaya untuk mengatasi permasalahan yang di alami siswa tersebut dengan cara memberikan bimbingan dan arahan. Dalam proses bimbingan, peneliti dan guru mitra memberikan kesempatan kepada siswa untuk terus berlatih baik dalam membaca maupun bercerita. Dengan tujuan agar siswa tersebut mampu memahami isi bacaan dan mengungkapkan isi bacaan dengan baik.

Dengan melihat kondisi siswa yang masih banyak mengalami kendala dalam menceritakan isi bacaan, maka peneliti mengambil langkah atau solusi dalam memecahkan persoalan tersebut dengan cara menerapkan pendekatan komunikatif. Karena pendekatan komunikatif merupakan salah satu kegiatan pembelajaran yang dapat menunjang proses pembelajaran bahkan dapat meningkatkan kemampuan siswa menceritakan isi bacaan.

Menurut Sani (2013:267) pendekatan komunikatif mengarahkan pengajaran bahasa pada tujuan pengajaran yang mementingkan fungsi bahasa sebagai alat komunikasi. Pendekatan komunikatif dianggap pendekatan yang efektif dalam meningkatkan kemampuan siswa menceritakan isi bacaan karena salah satu kelebihan dari pendekatan komunikatif yaitu melatih siswa dalam pengunaan bahasa untuk berkomunikasi dan dapat direalisasikan dalam kehidupan nyata.

Kemudian dilihat dari karakteristik dan ciri-ciri, pendekatan komunikatif Menurut Effendy (dalam Syakur, 2009:168-169), sebagai berikut: a) Tujuan 


$\begin{array}{ll}\text { Volume } & : 04 \\ \text { Nomor } & : 03 \\ \text { Bulan } & : \text { September } \\ \text { Tahun } & : 2018 \\ \text { http } & : / / \text { jurnal.pps.ung.ac.id/index.php/AKSARA/index }\end{array}$

pembelajarannya ialah mengembangkan kompotensi siswa berkomunikasi dalam situasi kehidupan yang nyata. b) Salah satu konsep mendasar dari pendekatan komunikatif adalah kebermaknaan dari setiap bentuk bahasa yang dipelajari. c) Dalam proses belajar mengajar, siswa bertindak sebagai komunikator. Sedangkan pengajar berperan sebagai fasilitator. d) Kegiatan dalam kelas diwarnai secara nyata dan dominan oleh kegiatan-kegiatan komunikatif. e) Materi yang disajikan beragam, f) Penggunaan bahasa ibu dalam kelas tidak dilarang tapi diminimalkan g) Dalam pendekatan komunikatif, kesilapan siswa dapat dimaklumi untuk mendorong keberanian siswa berkomunikasi. h) Evaluasi dalam pendekatan komunikatif ditekankan pada kemampuan menggunakan bahasa dalam kehidupan nyata, bukan pada penguasaan struktur bahasa atau gramatika.

Penerapan pendekatan komunikatif dalam pembelajaran bercerita dapat meningkatkan kemampuan siswa menceritakan isi bacaan dapat dilihat dari kelebihan, karakteristik dan ciri-ciri yang dimiliki oleh pendekatan komunikatif tersebut. Kemampuan siswa yang diperoleh pada siklus II, menunjukkan bahwa pelaksanaan tindakan kelas pada siswa kelas IV SDN 1 Limboto Barat Kabupaten Gorontalo telah mencapai hasil yang diharapkan sesuai dengan kriteria keberhasilan yang telah ditetapkan. Atas dasar tersebut, peneliti berkesimpulan bahwa menggunakan pendekatan komunikatif dalam menceritakan isi bacaan dapat meningkatkan kemampuan menceritakan isi bacaan.

Dengan demikian hipotesis tindakan kelas yang berbunyi "jika guru menggunakan pendekatan komunikatif dengan tepat maka kemampuan siswa menceritakan isi bacaan kelas IV SDN 1 Limboto Barat Kabupaten Gorontalo dapat ditingkatkan, dapat diterima".

\section{Simpulan}

Berdasarkan hasil penelitian dapat disimpulkan bahwa dengan melalui pendekatan komunikatif, kemampuan siswa kelas IV SDN 1 Limboto Barat Kabupaten Gorontalo dalam menceritakan isi bacaan meningkat.

Dari hasil penelitian di atas, penulis mengemukakan saran bahwa hasil penelitian ini diharapkan dapat menjadi bahan masukan bagi guru untuk menerapkan pendekatan komunikatif khususnya pada mata pelajaran bahasa Indonesia khususnya materi menceritakan kembali isi bacaan. Oleh karena guru harus memberikan perhatian khusus dan bimbingan kepada siswa yang belum mampu menceritakan kembali isi bacaan dengan baik. Untuk Peneliti selanjutnya, diharapkan dapat menggunakan hasil penelitian sebagai referens

\section{DAFTAR PUSTAKA}

Dhieni Nurbiana dkk. 2005. Metode Pengembangan Bahasa. Pusat Penerbitan Universitas Terbuka Departemen Pendidikan Nasional. Jakarta.

Nurgiyantoro Burhan. 2012. Penilaian Pembelajaran Bahasa. BPFE. Yogyakarta

Sani Ridwan Abdullah, 2013. Inovasi Pembelajaran. Bumi Aksara. Jakarta 
Subyantoro, 2013. Pembelajaran Bercerita: Model Bercerita Untuk Meningkatkan Kepekaan Emosi Dalam Berapresiasi Sastra. Ombak. Yogyakarta

Syakur Nazri. 2009. Kognitivisme Dalam Metodologi Pembelajaran Bahasa. Insan Madani. Yogyakarta

Tampubolon Saur. 2014. Penelitian Tindakan Kelas: Sebagai Pengembangan Profesi Pendidik Dan Keilmuan. Erlangga. Jakarta

Uno Hamzah B. 2010. Profesi Kependidikan: Problema, Solusi, Dan Reformasi Pendidikan Di Indonesia. Bumi Aksara. Jakarta

Khasanah Uswatun. 2016. Penerapan Modalitas Belajar dalam Meningkatkan Kemampuan Membaca Permulaan Siswa Kelas I di SDN 2 Kabila Kabupaten Bone Bolango. Skripsi. Universitas Negeri Gorontalo. Gorontalo.

Milman $\quad$ Yusdi. 2010. Pengertian Kemampuan. http://milmanyusdi.blogspot.co.id/2011/07/pengertiankemampuan.html. (Diakses 12 November 2016, 09:00)

Muttaqin Firdaus. 2013. Peningkatan Keterampilan Bercerita Melalui Pendekatan Savi Berbantuan Boneka Tangan Pada Siswa Kelas II SDN Karanganyar 01 Semarang. Skripsi. Universitas Negeri Semarang. Semarang. Htt://Lib.unnes.ac.id/19777/1/1401409011.Pdf. (Diakses 11 Maret 2017, 10:00)

Ningsih Suwarti. 2014. Peningkatan Keterampilan Berbicara Melalui Metode Bercerita Siswa Kelas III SD Negeri 1 Beringin Jaya Kecamatan Bumi Raya Kabupaten Morowali. Jurnal. File:///c:/Docume-1/Admini-1/Locals1/Temp/3990-12749-1-PB.Pdf. (Diakses 15 Desember 2016, 19:00)

Widasari Rahayu Hardini. 2012. Hubungan Penguasaan Kosakata Dengan Keterampilan Bercerita Siswa Kelas V SD Negeri Sekecamatan Wonosari Kabupaten Gunung Kidul. Skripsi. Universitas Negeri Yogyakarta. Yogyakarta. Http://eprints.uny.ac.id/7805/3/bab2-08108244047.Pdf. (Diakses 11 Maret 2017, 10:00) 